\title{
Book Review: Aullón de Haro, P. (ed.) (2015). Historiografía y Teoría de la Historia del Pensamiento, la Literatura y el Arte. Madrid: Dykinson.
}

\author{
Esther Zarzo \\ Department of Spanish studies \\ University of Alicante, Spain
}

Received: 02-12-2015

Accepted: 03-01-2016

Published: 01-04-2016

doi:10.7575/aiac.ijclts.v.4n.2p.1

URL: http://dx.doi.org/10.7575/aiac.ijclts.v.4n.2p.1

Historiografia y Teoría de la Historia del Pensamiento, la Literatura y el Arte is the latest publication by the Research Group "Humanism-Europe", led by Prof. Aullón de Haro from the University of Alicante, Spain. A radically comparative work, prepared with a team spirit, that presents in a single volume the result of a body of research that has been maturing for two decades.

Since 1994, when the Research Group was first founded -with the aim to highlight the relevance of Juan Andrés as the creator of the History of universal and comparative literature through the Group's publication of his work Origen, progresos y estado actual de toda la literatura (1997)-, a reflection on the Historiography and the Theory of History has been an on-going work, having been partially published in the now defunct university magazine Teoria/ Crítica (1994). During the maturation of this work other very remarkable works by the Group have been brought to light, such as Metodologías Comparatistas y Literatura Comparada (2012), and the seven volumes that make up the Teoria del Humanismo (2010). Now, with the approaching of the bicentennial of Juan Andrés' death (1740-1817), Historiografia y Teoría de la Historia del Pensamiento, la Literatura y el Arte has been published as the first contribution to the marking of this anniversary.

The need for this reflection on Historiography lies, as the director of the Group explains in the Preface, in the need to overcome the progressive reductionism established in modern times, which has led to the current-day situation. Synthesizing its argument, while it is true, in the opinion of Prof. Aullón de Haro, that during modernity Historiography reached its highest relevance and depth, it is also true that due to the progressive internal and external fragmentation of its object into various specialized and disconnected branches, besides the divisions of country and language, it has lost sight of what its specific objective and its fields of study are. This is especially a result of a timeless definition of the object of study, which ended in both the generation of contempt for Historiography, and for the humanistic object in general.

The reorganization of disciplines conducted by Enlightenment had some mixed effects on the historiographical discipline, deeply undermining its relationship with human time, a relationship that the imposition of structuralformalism finished off, eliminating the concepts of time and history from the field of Human Sciences, leading these to an impoverishing assimilation into disciplines of a sociological nature. Human Sciences, and the emphasis placed here, are not sociology.

Currently, this humanistic impoverishment inherited from modernity reaches its culmination by the widespread educational reorientation in favour of simple work practices that ignore traditional humanistic arts, from the art of reading to the art of memory, and humanistic literary, artistic or philosophical subjects, properly understood in their complete and related entity, as their world of existence requires.

This volume aims to contribute to a historiographical recreation of the History of Thought, Literature and Art, epistemologically founded in the Human Sciences framework. All this with the hope of a universal, comparative and humanistic historiography, as a response and contribution to our Globalization era, governed by the inertia of its economic-financial and cybernetic nature, on the margins of both the interpretation of culture and history, and of a moral concept that goes beyond simplistic political correctness.

The work, composed of twenty-nine chapters, approaches the problem of the dissolution of the literary historiography that took place during the past century, analysing its three main aspects: ontological isolation, which requires clarification of exactly what it is to be understood as historiography and its object, literature; the isolation of the discipline, which leads to the discipline issue, the issue of discourse, the terms of relationship and the literary genres; and the problem of national isolation, which demands making explicit the false identification between literature and language, as the trend to establish divisions of the literary object using nations as basis has resulted in the cancellation of its original possibility of universal scope. Here come into play, then, the shortcomings of a history of translation and of the non assumed comparative relations. Therefore, the work has been divided into three parts depending on the problem addressed. The result will be the redefinition of the concept of literature, liberating it from its assimilation to a unilateral artistic discourse, i.e., a poetic, narrative or dramatic discourse, and to consider literature every highly 
developed discourse, along with the liberation of the concept of literature from identification with the national language. And finally, the establishment of literature as a universal mode of experience and humanistic expression, and the subsequent need for its universal and comparative historiographical treatment, that founds a culture of a global nature.

After the initial chapter by the editor, "Introducción a una Epistemología historiográfica como Historia universal de las Ideas y las Formas literarias y artísticas" come three chapters dedicated to clarifying concepts and terms in order to overcome misunderstandings and inherited problems. The chapters "Historia de los términos 'Historia'/ 'Historiografía'" by Juan Francisco Mesa-Sanz, "Historiografía griega y método comparatista" by Alfonso Silván, and "El concepto de 'Historia' y su campo terminológico en las fuentes enciclopédicas modernas" by M ${ }^{\mathrm{a}}$ Teresa del Olmo, serve this purpose. The main range of concretions are exposed next, as well as the recent theory of the history of concepts, with "Historiografía e Historia de la filosofía" by Fernando Perez Herranz; "Verdad y tiempo en la historiografía de la Historia de la Filosofía: Kant y las derivas del método kantiano" by Ángel Poncela González; and "La Historia de los conceptos y su relación con la historia de la filosofía y la historia social" by Antonio de Murcia Conesa.

The second part proceeds with the reconstruction of literary historiography as a discipline, using a large series of paradigms, which are either fundamental to the great fields inherited or characterize the extremes and singularities. It begins with "La evolución de la historiografía literaria clásica" by José Joaquín Caerols; "Una síntesis de la historiografía patrística" by Fernando Rivas; "Historiografía de la traducción", a chapter shared by Francisco Lafarga and Luis Pegenaute; "La historiografía estética: pasado y presente", completely realised for the first time by Vicente Carreres; " Introducción a la 'Historia de la Ciencia' como género " by Javier Hernandez Ariza; "Musicología histórica e historiografía" by Teresa Cascudo; "La historiografía artística: las artes plásticas" by Javier Portús; and "Historiografía y cine" by José Carlos Rueda.

The third part addresses the opening up to the Middle East, Asia, Africa and America, trying to interpretively characterize and to reconstruct, selectively, the horizon of literary historiographies as large fields, without losing sight of the comparative sense, intended to set up a sense of universality as a way of overcoming the national divisions and restrictions. All this is addresssed in chapters by Ana Agud, "Una historiografía difícil: India"; "El estudio comparatista de la historia literaria de Asia del Este según Cho Dong-Il", prepared by Lee Hye-Kyung; by Alfonso Falero, "Hacia una historiografía literaria en Japón"; by Isaac Donoso, "Historiografía de las letras filipinas". Meanwhile, the two large blocks of American historiography are solved by Ricardo Miguel Alfonso with "Evolución de la historiografía literaria angloamericana"; and by Efrain Kristal with "En torno a la historia del concepto de historia literaria hispanoamericana"; plus the study on Brazil, by Margarida Maia Gouveia: "Análisis de la historiografía literaria en Brasil". Thirdly, Rosario Martí Marco reconstructs "La historiografía literaria alemana"; Jesús García Gabaldón "La evolución de la historiografía literaria eslava" and Natalia Timoshenko completes the historiographical reconstruction with an "Introducción a la historiografía literaria rusa". There is not any monography reconstructing a Roman historiography (Spanish, French, Italian) as this is the most comprehensive and less problematic field in regard to availability and is the best known to Western readers.

And finally, the African world, including chapters by Antonio Constán Nava, with "Historiografía árabe islámica (Siglos XVIII-XX) Perspectiva española y europea"; by José Manuel Mora Fandos with "La historiografía de la literatura Africana"; and by M'bare M'gom, whose article "Sobre la historiografía literaria hispanoafricana" serves both to complement and as conclusion to this volume.

According to the editor, Aullón de Haro, the idea of action and human sense depends on the concept and knowledge of history. The possibility to overcome the decline of the discipline -and even civilizational- divisions depends on an alive historical self-consciousness. After the fall of structural-formalism, a form of self-consciousness has ended, being now necessary to re-establish a historiographical methodology of ethical, critical and humanistic value, and with this, a philosophical, literary and artistic History: a project capable of assuming a conception of the object as synthesis of idea and form, and where it is universal, not the mere sum of parts. With this contribution, the Research Group HumanismEurope provides a tool for examining a great humanistic problem that now, for a necessarily common future, demands a proper interpretation, in accordance to this current era of Globalization.

\section{References}

Andrés, J. (1997). Origen, progresos y estado actual de toda la literatura. J. García Gabaldón, S. Navarro Pastor, C. Valcárcel (Eds.). C. Andrés, S. Navarro Pastor (Trad.). P. Aullón de Haro (Dir.). Madrid: Verbum-Biblioteca Valenciana, 6 vols.

Aullón de H. , P. (ed.) (1994). Teoría y Crítica I. Teoría de la historia, de la literatura y el arte. Revista publicada por el Seminario de Teoría de la Literatura y Literatura Comparada de la Universidad de Alicante. Madrid: Verbum.

Aullón de H. , P. (ed.) (2012). Metodologías Comparatistas y Literatura Comparada. Madrid: Dykinson.

Aullón de H. , P. (ed.) (2010). Teoría del Humanismo. Madrid: Verbum, 7 vols.+ DVD. 